\title{
Making Glass Bottles
}

For thousands of years since its development in Syria, manufacturing glass objects was considered an art. Difficulty in controlling viscosity, heat transfer, and nonlinear relaxation properties of glass made that industry one of the last to be mechanized by the industrial revolution.

After the blowpipe was invented in about 100 B.C., the process of making hollow glass containers changed little until the 1880 s. Indeed, the most significant earlier developments were the foot-operated bellows (1679) and crossfire burners (1790).

But beginning in 1882, four decades of rapid and remarkably creative innovation brought the glass industry into modern times. Mechanical horsepower applied within the glass industry during 1880-1920 increased 36 -fold, compared with an average 8-fold increase in other industries. Where the scarcity and cost of skilled labor had restricted the uses of hand-blown glass containers, mechanization made possible low-cost glass bottles. Labor unions eventually applauded the mechanization they had resisted when jt became clear the booming demand for glass would support many more jobs with better working conditions than before.

Edward Meigh profiled a dozen pioneers in mechanizing glass bottle making in the premiere issue of Glass Technology (1960). Philip Arbogast of Pittsburgh and Howard Ashley of England independently (in 1881 and 1886 , respectively) determined that three steps are essential to making bottles with machines: (1) form the neck and mouth of the bottle first, (2) create an intermediate "parison" before (3) finally blowing the glass into a separate final shaping mold. In 1898, but apparently independently as well, a brash uneducated American, Michael J. Owens, began his remarkable bottle making experiments.

The son of an Irish immigrant coal miner in West Virginia, Owens was forced to work at age 10 to support his widowed mother. He learned the glass trade - and the deplorable conditions prevalent for child workers in those days - in a Wheeling flint glass plant. He became active in the glass workers union. In 1888 Owens joined what was to become the Libbey Glass Company as a second-ranking glass blower in the Toledo plant. Within two years, Edward D. Libbey named him plant superintendent.

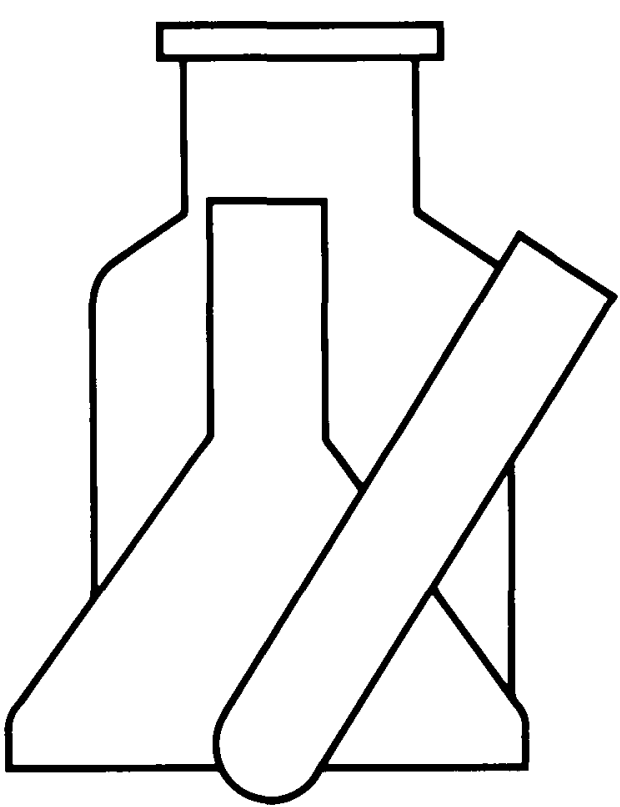

While in charge of the company's exhibit at the 1893 Columbian Exhibit in Chicago, Owens conceived his first ideas for mechanical glass blowing. The Toledo Glass Company was formed to develop Owens' machines. A diplomatic manager, Libbey supported the "uncultured, ungrammatical, egotistic, arrogant, domineering" Owens through six experimental machines, often without the support of his co-directors. Beginning in 1903, twelve different production machines followed and became industry standards. The most capable - the CA and CB models introduced in 1920 - had 15 bottle making arms and could make up to 320 bottles a minute! This single machine could produce more and better quality bottles than 450 skilled hand operators.

At first, the Owens Bottle Machine Co., founded by Owens and Libbey, licensed the bottle making machines for use by others. But when they decider. 's manufacture bottles as well, Libbey ai:a Owens had to beg their exclusive licensees to sublicense rights back to the inventors. They ultimately bought up many of the licensees, forming Owens-Illinois, for example, after restoring licenses granted to the Illinois Glass Co.
The weaknesses of Owens' machines were energy inefficiency and their awkward handling of molten glass streams using either suction or gravity. A breakthrough came in 1915 when a Massachusetts Institute of Technology trained engineer, Karl E. Pieler, rejected streams of molten glass and successfully automated the manual glass blowing technique of gathering and cutting a "gob" of molten, viscous glass from the lip of the supply bowl. The invention was called the Hartford paddle feeder after the Connecticut location of Pieler's employer, Honiss \& Lorenz, an engineering and patent attorney firm. Pieler's invention was the first that could consistently deliver a predetermined weight of the pear-shaped molten glass gobs to the forming machines. Three years later a paddle-needle feeder was developed to better handle glass for narrow-necked bottles. The paddle-less Hartford single feeder, which could operate over a wider range of speeds, was developed in 1922. The various improved versions of this feeder were used in the vast majority of bottle making machines.

Ironically, the rights to the gob feeder were offered for sale to the industry leader - the Owens Bottle Machine Co. shortly after its invention. Despite his experience as a glass blower, Owens was said to have refused the offer after only a superficial review, in what was called one of Owens' worst decisions. In 1920, Owens began to use the Hartford feeder and became a leading licensee of the technology, though surely at much greater cost than if Owens had bought the technology just a few years earlier.

Given his background, however, it may not have been coincidental that Owens' inventions essentially halted child labor in the glass industry. In 1880 some $23 \%$ of bottle industry workers were under 16 years old. Forty years later, after the Owens machines were well established, the figure was less than $2 \%$. In an unsolicited letter to Owens in 1913, the National Child Labor Committee said the rapid introduction of the Owens machine in the glass industry had done more to eliminate child labor than had the committee's legislative efforts.

M. ROSS 